\title{
Feeding strategy of early juvenile stages of the southern king crab Lithodes santolla in the San Jorge Gulf, Argentina
}

Estrategia de alimentación de los estadios juveniles tempranos de la centolla Lithodes santolla en el Golfo San Jorge, Argentina

\section{Julio H. Vinuesa ${ }^{1,2}$, Martín A.Varisco ${ }^{1,2}$ and Pamela Balzi ${ }^{1}$}

${ }_{1}^{1}$ Instituto de Desarrollo Costero, Universidad Nacional de la Patagonia San Juan Bosco, Ruta 1 km. 4, (9000), C. Rivadavia, Chubut, Argentina

${ }^{2}$ Consejo Nacional de Investigaciones Científicas y Técnicas. julio.vinuesa@gmail.com.

\begin{abstract}
Resumen.- Se analizó el contenido estomacal de 313 ejemplares juveniles de centolla de ambos sexos con longitudes de caparazón (CL) entre 8,40 y 49,04 mm, estudiándose la influencia del sexo, talla, estado de muda y estación del año. Los animales fueron capturados mediante buceo en muestreos estacionales en el infralitoral rocoso del área central del Golfo San Jorge. Se determinó la frecuencia de ocurrencia (FO) y abundancia relativa (AR) de las presas halladas, estado de repleción y peso del contenido estomacal. Se registró un 14,4\% de animales con el estómago vacío, un $55,1 \%$ con repleción menor del $50 \%$ y un 30,5\% mayor al 50\%. Los juveniles no se alimentan antes de mudar, durante la muda ni en postmuda reciente. Se identificaron 27 grupos de presas diferentes, incluidas varias especies de algas, protistas e invertebrados. Las mayores FO fueron registradas en algas coralináceas $(45,1 \%)$, ofiuroideos $(34,8 \%)$, equinoideos $(25,1 \%)$, isópodos $(21,7 \%)$, moluscos bivalvos $(19,5 \%)$, poliquetos $(16,9 \%)$ y briozoos $(15 \%)$. En términos de $A R$, los principales componentes de la dieta fueron ofiuroideos, isópodos y coralinaceas. La composición de la dieta es diferente en animales menores de $15 \mathrm{~mm} \mathrm{CL}$ de aquellos mayores a esa talla, debido a la mayor abundancia de isópodos y briozoos en este intervalo. La gran diversidad de presas registradas indica que los juveniles son esencialmente depredadores macrófagos y omnívoros, que aprovechan los complejos hábitats infralitorales rocosos y biogénicos del área estudiada para su alimentación y refugio durante los primeros años de vida.
\end{abstract}

Palabras clave: Dieta, depredación, Lithodes santolla, juveniles, aguas costeras, omnivoría

Abstract.- Stomach content analysis was performed on 313 juveniles of Lithodes santolla, with carapace lengths (CL) measuring between 8.40 and $49.04 \mathrm{~mm}$. The influence of season, sex, size and moult stage on their diet were studied. Crabs were captured seasonally from the rocky sublittoral zone in the central area of San Jorge Gulf using SCUBA. The frequency of prey occurrence (FO), relative abundance (RA), degree of fullness and the stomach content weight were registered. Empty stomachs were found in $14.4 \%$ of the specimens, while stomach fullness below $50 \%$ occurred in $55.0 \%$ of crabs and over $50 \%$ in $30.6 \%$ of crabs. Juveniles did not feed prior to and immediately after moult. A total of 27 prey groups were identified, which included several species of algae, protists and invertebrates. The higher FO was observed for coralline red algae $(41.5 \%)$, ophiuroids $(34.8 \%)$, echinoids $(25.1 \%)$, isopods $(21.7 \%)$, bivalves (19.5\%), polychaetes (16.6\%) and bryozoans (15.0\%). In terms of RA, the main prey items were ophiuroids, isopods and coralline red algae. No significant differences were found in the amount of food consumed and diet composition between sexes. A seasonal variation in the prey species composition was recorded. The diet of crabs smaller than $15 \mathrm{~mm} \mathrm{CL}$ differed significantly from that of larger juveniles, due to a higher abundance of bryozoans and isopods in smaller juveniles. The great diversity of prey found in juvenile king crab indicates that they are macrophages and opportunistic omnivorous predators, which take advantage of complex rocky and biogenic subtidal habitats for food and shelter.

Key words: Diet, predation, Lithodes santolla, juvenile, coastal waters, omnivory

\section{INTRODUCTION}

The southern king crab (SKC) or 'centolla' Lithodes santolla (Molina, 1782) is a common decapod crustacean found on the southern tip of South America. Among the 3 species of the genus found in southern Chile and Argentina, L. santolla shows the largest body size and highest population abundance. Lithodes confundens
Macpherson, 1988, is frequent along the Atlantic Patagonian and Fuegian coasts, from approximately $50^{\circ} \mathrm{S}$ south, near the Malvinas (Falkland) Islands and the Magellan Strait (Macpherson 1988, Vinuesa et al. 1999). It is caught for sport in the south of the Argentine province of Santa Cruz and in the Isla Grande of Tierra 
del Fuego. The smallest of the 3 species, Lithodes turkayi Macpherson 1988, is a non-commercial species and occurs below depths of about $70 \mathrm{~m}$ in the south of Chile (Revuelta \& Andrade 1978), Malvinas Islands and the Beagle Channel (Vinuesa et al. 1999).

One of the most important populations of L. santolla is found in San Jorge Gulf and surroundings, where it is a commercially valuable species. The gulf is the largest semiopen basin of the South-western Atlantic Ocean, covering an area of about $40,000 \mathrm{~km}^{2}$. Adult SKC are known to occur almost all over the gulf and in deeper shelf waters outside the gulf and further north (Vinuesa 2005).

The species breeds in the area once a year, mainly in December, and embryogenesis extends for up to 10 months (Vinuesa \& Balzi 2002). Larvae pass through 3 zoea stages and a megalopa stage (Campodónico 1971, Vinuesa et al. 1985), with a complete larval development described as lecithotrophic (Kattner et al. 2003, Lovrich et al. 2003, Anger et al. 2004, Calcagno et al. 2004). However, facultative functionality of mouth appendages may appear in the megalopa stage (McLaughlin et al. 2003).

Larval development takes about 70 days in culture conditions (Calcagno et al. 2004). However, the time of development from hatching to successive stages is greatly influenced by temperature. In a previous study, at an average temperature of $5.5^{\circ} \mathrm{C}$, the megalopal stage was reached in $25-31$ days, whereas at $7.5^{\circ} \mathrm{C}$ and $9.5^{\circ} \mathrm{C}$ this was reduced to 18 to 24 days respectively (Vinuesa et al. 1985). Anger et al. (2004) indicates that at the colder water temperatures of the Beagle Channel, megalopa reach metamorphosis to first crab instar in ca., 60 days (Anger et al. 2004). There is also greater growth in juveniles with increasing temperature, due to the shortening of the intermoult period (Calcagno et al. 2005). Here, crab stage 5 was reached after 100 days at $15^{\circ} \mathrm{C}$, but after about 200 days at $9^{\circ} \mathrm{C}$, with an approximate size between 4.2 and 5.4 $\mathrm{mm}$ CL. Sexual dimorphism was clearly evident at stage 5 , due to the asymmetry observed in abdominal plates (McLaughlin et al. 2001).

The trophic role of lithodids has been thoroughly studied because they often constitute a major part of the benthic invertebrate biomass. This is the case, for example, of the red king crab, Paralithodes camtschaticus (Tilesius,
1815), whose feeding habits was studied in many areas of its distribution range (Feniuk 1945, Takeuchi 1959, 1967; McLaughlin \& Hebard 1961, Tarverdieva 1976, Feder et al. 1980, Feder \& Jewett 1981, Jewet \& Feder 1982, Jewett et al. 1990).The diet of the golden king crab, Lithodes aequispina Benedict, 1895, studied in the Bering Sea and the Sea of Okhotsk, was comprised of nearly 20 groups of prey in adults, but only 10 in juvenile crabs (Tarverdieva \& Zgurovsky 1985). Stomach-content analysis of SKC has been done only for large juveniles and adults from the Beagle Channel (Comoglio et al. 1990) and for adults in the San Jorge Gulf (Balzi 1997).

Food supply is an important factor for nursery habitat selection in early juveniles of several decapods species (Herrnkind \& Butler 1986, Pirtle \& Stoner 2010, Vinuesa et al. 2011). There is little information on the diet of $L$. santolla during the first years of the juvenile phase, when crabs occupy an entirely different habitat from adults. In the San Jorge Gulf, small juvenile SKC occur in shallow rocky areas along the coast. They are usually found within holes, crevices, small caves and channels, on sections of large and small boulders and cobbles, supporting abundant vegetation and a rich sessile fauna (Vinuesa 2001). Recent studies conducted in the area have highlighted the complexity and high biodiversity of the rocky subtidal, identifying over 120 macrobenthic species (Vinuesa 20081). This suggests that juveniles would feed on a portion of the biota and may find shelter from predators, mainly at early developmental stages.

The productivity of this fishery resource depends partially on the settlement success and recruitment level in their habitats. This fact emphasizes the importance of performing diet analysis at early development stages of SKC in order to gain a better understanding of its role in the coastal food web. The settlement and recruitment of the species in the area was confirmed previously when small juveniles between 2.42 and $3.73 \mathrm{~mm}$ carapace length were found on artificial collectors (Vinuesa $2008^{1}$ ). The objectives of this study were to determine the diet composition of SKC juveniles inhabiting subtidal rocky areas of the San Jorge Gulf, and to assess diet changes related with sex, size, moult stage, and season. We hypothesized that early juveniles of SKC are macrophages and opportunistic omnivorous predators.

\footnotetext{
${ }^{1}$ Vinuesa JH. 2008. Dinámica del asentamiento de poblaciones bentónicas en fondos duros del Golfo San Jorge. Informe Final. Subproyecto A-B-67. Proyecto 'Prevención de la contaminación costera y gestión de la diversidad biológica marina' (World BankGEF-UNDP), 75 pp.
} 


\section{MATERIALS AND METHODS}

\section{STUDY AREA}

Early juveniles of $L$. santolla were randomly collected from rocky bottoms in the subtidal nearshore, over a distance of nearly $2 \mathrm{~km}$ (ca., 4603'S). The sampling area is located to the south of Comodoro Rivadavia city, has a semi-diurnal tidal regime and the minimum and maximum historical temperatures are $4.1^{\circ} \mathrm{C}$ in winter and $19.3^{\circ} \mathrm{C}$ in summer, respectively (Servicio Hidrografía Naval 2007²). There are extensive forests of the kelp Macrocystis pyrifera (L.) Agardh, in almost all the rocky sublittoral zone along the coastal sampling area, mixed in some areas with the increasingly invasive seaweed Undaria pinnatifida (Harvey) Suringar. Crabs were caught in seasonal samplings, during 2006 and 2007, by scuba diving at depths between 1 and $15 \mathrm{~m}$ (Table 1). Upon removal from the water, crabs were immediately fixed in $7 \%$ formalin solution in seawater until further processing at the laboratory.

\section{LABORATORY PROCEDURES}

The crabs were sexed and their carapace length (CL) measured from the base of the rostrum to the posterior medial margin of the carapace with a digital calliper to the nearest $0.01 \mathrm{~mm}$. Each juvenile was assigned to one of the following 5 moult stages: 1) Moulting (MOU): carapace and/or legs are partially detached, or there are remnants of exocuticle. 2) Recent post moult (RPM): soft, non-calcified and bright red carapace, without epibiosis. 3) Late post moult (LPM): coriaceous or partially hardened carapace; legs non-calcified yet; reddish in colour and epibiosis on carapace and legs cannot be macroscopically distinguished, if it exists. 4) Intermoult (INT): rigid carapace, in general lightly calcified, more or less opaque and reddish orange in colour; chelipeds and legs are also lightly calcified; with or without visible epibiosis. 5) Premoult (PMO): harder carapace, opaque and reddish or brownish in colour; the formation of a new carapace underneath the hard one is visible in later phases of this stage; with or without visible epibionts.

The entire stomach was dissected out and the degree of stomach fullness was estimated arbitrarily according to the amount of content in relation to the stomach volume in 3 categories: Empty (no content), low (lesser than 50\%), and high (greater than 50\%). The content was removed
Table 1. Seasons, date and sex of southern king crab juveniles captured during the study / Estación del año, fecha y sexo de los juveniles de centolla capturados durante el estudio

\begin{tabular}{lrccc}
\hline Season & \multicolumn{1}{c}{ Date } & Males & Females & Total \\
\hline \multirow{2}{*}{ Autumn } & $4 / 8 / 2006$ & 5 & 4 & 9 \\
& $5 / 7 / 2006$ & 34 & 23 & 57 \\
Winter & $7 / 14 / 2006$ & 12 & 6 & 18 \\
& $8 / 24 / 2006$ & 17 & 21 & 38 \\
& $8 / 8 / 2007$ & 3 & 7 & 10 \\
Spring & $10 / 28 / 2006$ & 10 & 12 & 22 \\
& $11 / 5 / 2006$ & 2 & 6 & 8 \\
& $11 / 11 / 2006$ & 23 & 14 & 37 \\
Summer & $1 / 18 / 2007$ & 57 & 57 & 114
\end{tabular}

carefully and weighed (stomach content wet weight, SCW) to the nearest $0.001 \mathrm{~g}$ and then examined under a stereoscopic microscope and, if necessary, in a compound microscope. The food items were identified to the lowest possible taxa. The frequency of occurrence of prey (FO) was determined for each food item. We also registered the relative abundance (RA) of each prey, as a percentage of total content in each stomach.

\section{STATISTICAL ANALYSIS}

The independence between the degree of stomach fullness and sex, size, season and moult stage was tested using separate chi-square tests. An analysis of covariance (ANCOVA) was used to compare SCW between sexes using $\mathrm{CL}$ as the covariate. The assumption of homogeneity of variances (Cochran test) and homogeneity of regression slopes among sexes was tested prior to performing the analysis (Sokal \& Rohlf 1995).

Diet composition was analysed in relation to season, sex, size class, and moult stage. The juveniles were grouped into 4 size classes (1: < 15; 2: 15-25; 3: 25-35; and 4: > 35 mm CL). One-way ANOSIM (similarity analysis) tests were performed for a qualitative (Ql) and quantitative (Qt) evaluation of the diet. The similarity matrix was calculated with the Sorensen (presence-absence) and Bray-Curtis (RA data) index, for qualitative and quantitative analyses, respectively. A similarity percentage (SIMPER) analysis routine was performed for those factors yielding significant differences in order to identify the percentage contribution of each taxon to any observed differences (Clarke \& Warwick 2001).

${ }^{2}$ Servicio Hidrografía Naval. 2010. Temperaturas de agua de mar en superficie. Servicio de Hidrografía Naval, Ciudad Autónoma de Buenos Aires. <http://www.hidro.gov.ar/ceado/Ef/crivadav.asp> 


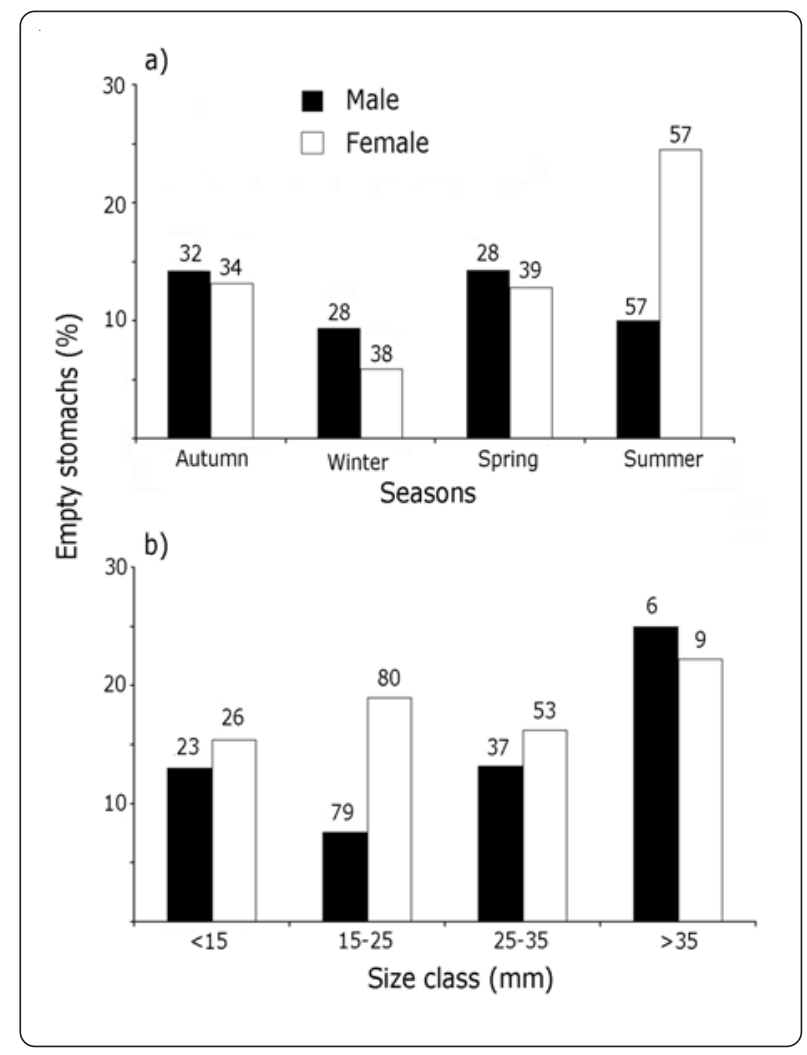

Figure 1. Percentage of empty stomachs and their relation to different seasons (a) and body size classes (b) of males and females of the southern king crab Lithodes santolla. Number of crabs is indicated in each case / Porcentaje de estómagos vacíos y su relación con las distintas estaciones del año (a) y la talla (b) de machos y hembras de la centolla Lithodes santolla. El número de individuos se indica en cada caso

\section{Results}

A total of 313 juveniles of $L$. santolla were collected during seasonal samplings on sublittoral rocky bottoms along the central coast of the San Jorge Gulf. Body size ranged between 8.40 and $49.04 \mathrm{~mm}$ CL. Of these, $51.7 \%$ were males and $48.3 \%$ were females. The sex ratio did not deviate significantly from the expected 1:1 ratio (Chi-square test, Yate's correction $=0.368 ; \mathrm{df}=1 ; P=0.54$ ).

Empty stomachs were found in $14.4 \%$ of the specimens, while low and high stomach fullness was found in $55.0 \%$ and $30.6 \%$ of the crabs, respectively. The proportion of empty stomachs was similar for both sexes (Yates's = $0.635 ; \mathrm{df}=1 ; P=0.42)$ and was independent of season (Yates's $=3.41 ; \mathrm{df}=3 ; P=0.33$ ) (Fig. $1 \mathrm{a})$ and size $(=0.52$; $\mathrm{df}=3 ; P=0.91$ ) (Fig 1b). A direct relationship was found between moult stage and degree of stomach fullness. Crabs in premoult (PMO), moult (MO) and recent postmoult (RPM) stages presented empty stomachs throughout the study period. Chitinous remains of the old stomach were found in only one recently moulted crab.

The stomach content weight (SCW) was positively related with the carapace length $(\mathrm{CL})$ in males $(r=0.60)$ and females $(r=0.56)$, with no significant differences between sexes (ANCOVA, $\mathrm{F}_{(1,264)}=0.13 ; P=0.71$ ) (Fig. 2). Crabs in PMO, MOU and RPM were not included in this analysis.

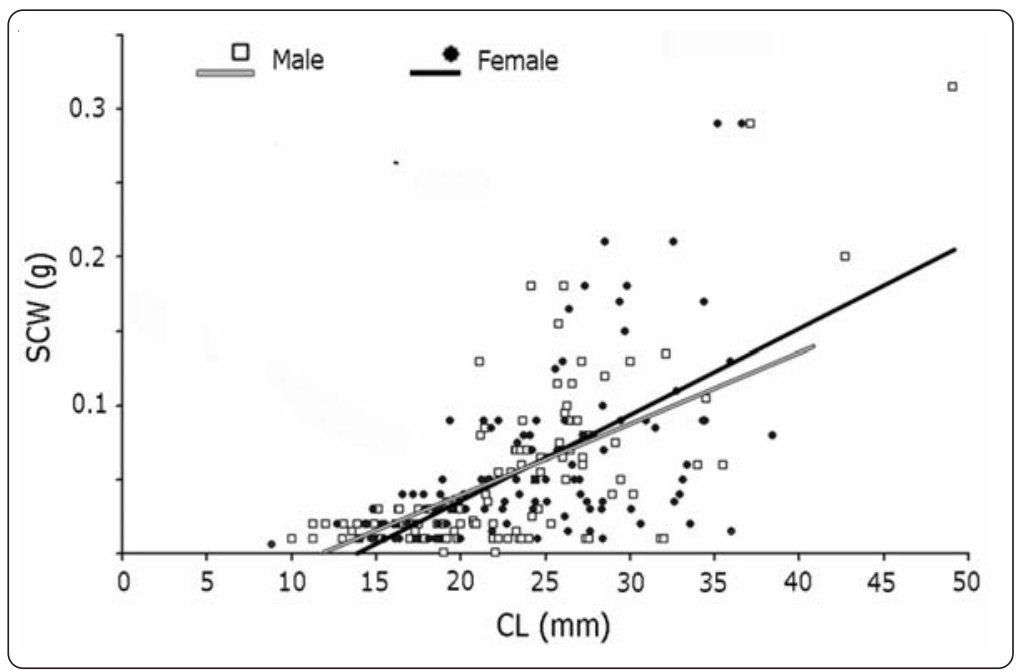

Figure 2. Relationship between stomach content weight (SCW) and carapace length (CL) of males and females of the southern king crab Lithodes santolla / Relación entre el peso del contenido estomacal (SWC) y la longitud del caparazón $(\mathrm{CL})$ de machos y hembras de la centolla Lithodes santolla 


\section{Diet Analysis}

The total number of crabs with prey in their stomachs was 268. Stomach contents showed highly fragmented material resulting from the combined physical action of chelipeds, mouthparts and gastric mill. Sediments had a minor contribution to the stomach fullness, with FO between 22 and 26\% in males and females, respectively. The diet composition was composed of 27 recognised prey groups, sediment, organic remains, and other unidentified crustaceans (Table 2). The most frequent components were the remnants of tissues in various stages of digestion and chitinous hard parts, registered as unidentified organic remains (UOR). A higher FO was observed for coralline red algae (41.5\%), ophiuroids (34.8\%), echinoids (25.0\%), isopods (21.7\%), bivalve molluscs $(19.5 \%)$, polychaete worms $(16.6 \%)$ and bryozoans (15.0\%). Lower FO was observed for phaeophytes, chlorophytes, cyanobacteria, benthic diatoms and foraminiferans, poriferans, hydrozoans, gastropods, polyplacophorans, amphipods, pycnogonids, harpacticoid copepods, decapods, and other taxa (Fig. 3). Ophiuroids ( $\mathrm{RA}=18.6 \%)$, isopods $(7.5 \%)$, red algae $(4.7 \%)$, bryozoans (4.5\%) and polychaete worms (2.8\%) were the most abundant items in the stomach of SKC in terms of relative abundance.
INFLUENCE OF SEASON, SEX, CRAB SIZE AND MOULT STAGE ON DIET COMPOSITION

No significant differences were found in the diet composition between sexes in qualitative (ANOSIM; $\mathrm{R}=$ $0.005, P=0.19)$ and quantitative terms $(\mathrm{R}=0.003, P=$ $0.26)$

The diet differed significantly among seasons at qualitative ( $\mathrm{R}=0.191, P=0.001)$ and quantitative levels ( $\mathrm{R}=0.201, P=0.001)$. Pairwise comparisons indicated that diet composition was similar only in winter and spring (Ql: $\mathrm{R}=0.005 P=0.29$; Qt: $\mathrm{R}=0.024, P=0.053$ ). The percentage contribution of the main prey items to the observed differences of the diet between seasons is shown in Table 3.

Significant differences in the diet among size classes were also recorded by presence/absence data $(\mathrm{Ql}: \mathrm{R}=$ $0.191, P=0.001)$, and RA of diet items (Qt: R statistic $=$ $0.061, P=0.001)$. Pairwise comparisons showed that the diet composition of specimens smaller than $15 \mathrm{~mm} \mathrm{CL}$ differed significantly from that of the rest of the size classes. This difference was due to a higher abundance of bryozoans and isopods in their stomach content, and the abundance of ophiuroids and echinoids in larger size crabs (Table 4).

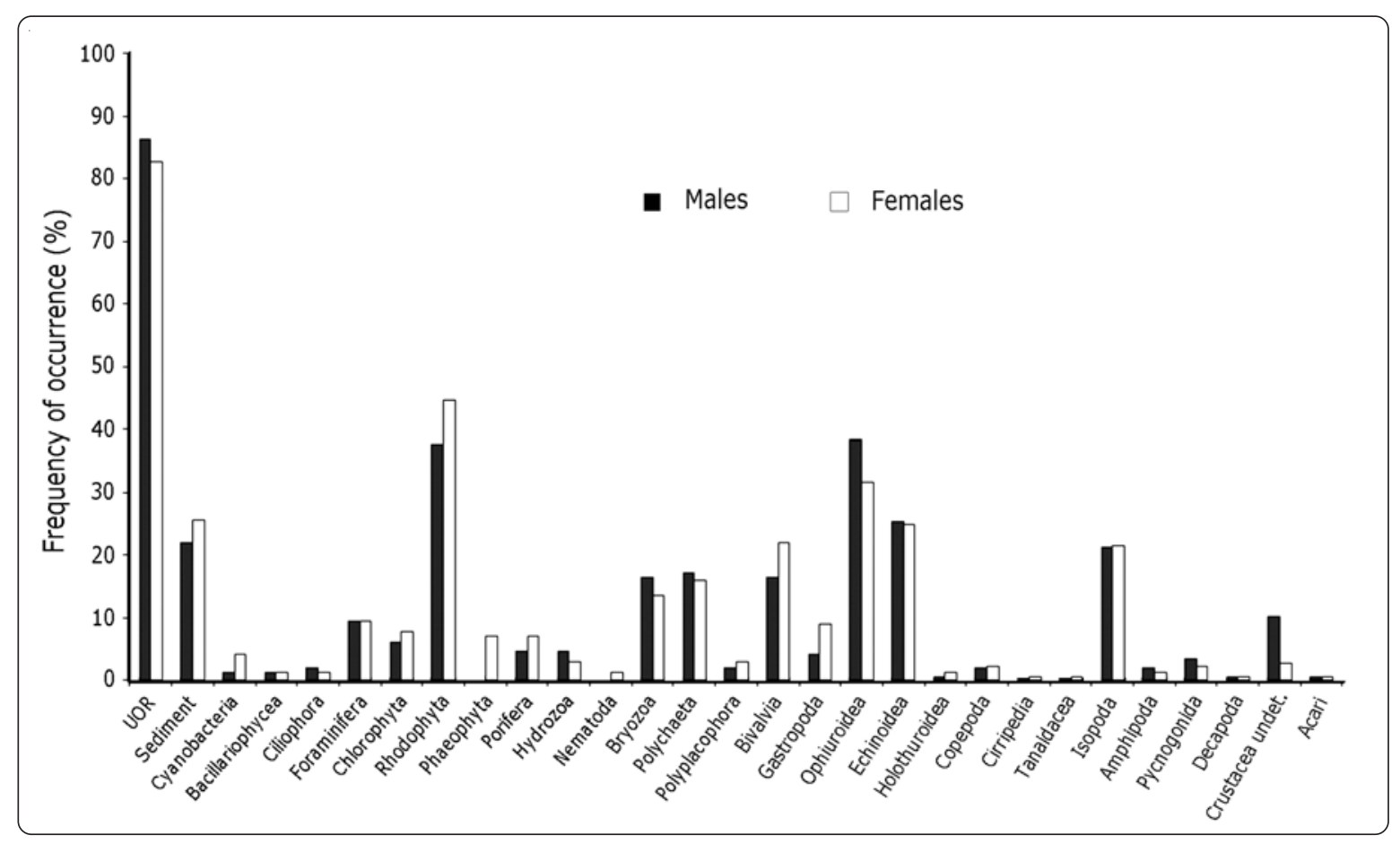

Figure 3. Frequency of occurrence of major taxa and materials found in the stomachs of juvenile SKC, separated by sex / Frecuencia de aparición de los principales taxa y materiales encontrados en los estómagos de los juveniles SKC, separados por sexo 
Table 2. Identified taxa in stomach content of southern king crab in the San Jorge Gulf / Taxa identificados en el contenido estomacal de juveniles de centolla en el Golfo San Jorge

\begin{tabular}{|c|c|c|}
\hline CIANOBACTERIA & NEMATODA & OSTRACODA \\
\hline Coleochaete sp. & Undetermined & Conchoecia sp. \\
\hline BACILLARIOPHYTA & BRYOZOA & CIRRIPEDIA \\
\hline Licmophora sp. & Celleporella sp. & Balanus sp. \\
\hline Navicula sp. & Membranipora isabelleana & TANAIDACEA \\
\hline CLOROPHYTA & Aetea anguina & Tanais sp. \\
\hline Enteromorpha sp. & Beania sp. & ISOPODA \\
\hline Codium sp. & POLYCHAETA & Exosphaeroma lanceolatum \\
\hline Ulva sp. & Ophryotrocha sp. & Neastacilla falklandica \\
\hline RHODOPHYTA & Platynereis sp. & Edotia sp. \\
\hline Heterosiphonia sp. & BIVALVIA & AMPHIPODA \\
\hline Polysiphonia sp. & Aulacomya atra atra & Caprella sp. \\
\hline Corallina officinalis & Lasaea sp. & Gondogeneia sp. \\
\hline Corallina elongata & Mytilus platensis & Jassa alonsoae \\
\hline Aphanocladia robusta & Carditella naviformis & Austroregia huxleyana \\
\hline Strebocladia camptoclada & Ameghinomia sp. & Paradexamine sp. \\
\hline Ceramium rubrum & Perumytilus purpuratus & Gammaropsis sp. \\
\hline Aglaeozonia sp. & GASTROPODA & DECAPODA \\
\hline PHAEOPHYTA & Paraeuthria sp. & Halicarcinus planatus \\
\hline Myriogloia sp. & Eatoniella sp. & zoea Anomura \\
\hline FORAMINIFERA & Fissurella sp. & PYCNOGONIDA \\
\hline Discorbis sp. & Ataxocerithium pullum & Colossendeis sp. \\
\hline Elphidium sp. & Nacella sp. & Tanystylus sp. \\
\hline Cibicides sp. & POLYPLACOPHORA & ACARI \\
\hline CILIOPHORA & Tonicia sp. & Halacarida \\
\hline Acineta sp. & Plaxiphora sp. & ECHINOIDEA \\
\hline PORIFERA & Leptochiton sp. & Pseudechinus magellanicus \\
\hline Undetermined & COPEPODA & OPHIUROIDEA \\
\hline CNIDARIA & Porcellidium sp. & Ophiactis asperula \\
\hline Lafoea fruticosa & Tigriopus sp. & HOLOTHUROIDEA \\
\hline $\begin{array}{l}\text { Symplectoscyphus sp. } \\
\text { Eudendrium sp. }\end{array}$ & Tisbe sp. & Pseudocnus sp. \\
\hline
\end{tabular}

No significant differences were observed in diet among late postmoult and intermoult stages in qualitative $(\mathrm{R}=$ $0.01, P=0.34)$ and quantitative terms $(\mathrm{R}=0.025, P=0.16)$. Crabs in premoult, moult and recent postmoult were not included in this analysis because most of their stomachs were empty.

\section{Discussion}

The present study indicated that the juveniles SKC are predominantly predators, omnivorous and macrophagous. In the San Jorge Gulf, they have a highly diversified diet composed of several species of algae, protists and invertebrates (see Table 3). Studies on the diet composition of SKC within its distribution area are scarce and mostly restricted to adult crabs. In the Magellan Strait $\left(\sim 53^{\circ} \mathrm{S}\right)$, the diet of adult SKC consisted mainly of crustacean and bryozoans (Stuardo \& Solís 1963). Posterior studies from the Magellan Strait and in the Beagle Channel $\left(\sim 54^{\circ} \mathrm{S}\right)$ found less than 20 prey items in the stomach contents of these adult crabs (Guzmán \& Ríos 1985, Comoglio et al. 1990). The adults in the San Jorge Gulf consumed a poorly diversified diet, suggesting that they are important scavengers that feed mainly on discards from fishing vessels and, to a lesser extent, on bivalve molluscs, gastropods and echinoderms (Balzi 1997).

There is little information on the natural feeding of postlarvae and early juveniles of Lithodidae. The dominant food items of postlarvae red king crab in the northern Pacific Ocean and Behring Sea were sponges, small crustaceans (copepods and ostracods), polychaetes, foraminiferans, diatoms, bryozoans and filamentous algae, together with a large amount of sediment and detrital 
Table 3. SIMPER comparisons among seasons in juvenile Lithodes santolla of the San Jorge Gulf / Comparaciones SIMPER entre las distintas estaciones del año en los juveniles de Lithodes santolla del Golfo San Jorge

\begin{tabular}{ccccccc}
\hline \multirow{2}{*}{ Comparisons } & Prey & \multicolumn{3}{c}{ Abundance in season } & $\begin{array}{c}\text { Dissimilarity } \\
\text { Contribution } \\
\text { (\%) }\end{array}$ \\
\cline { 3 - 6 } Summer - Autumn & Isopoda & 2.31 & 19.93 & & & 21.79 \\
& Bryozoa & 17.49 & 0.30 & & & 21.18 \\
& Ophiuroidea & 3.84 & 17.70 & & & 21.10 \\
Summer - Winter & Bryozoa & 17.49 & & 0.00 & & 22.81 \\
& Ophiuroidea & 3.84 & & 17.51 & & 22.21 \\
& Isopoda & 2.31 & & 4.64 & & 8.80 \\
Spring - Summer & Bryozoa & 17.49 & & & 0.00 & 29.03 \\
& Ophiuroidea & 3.84 & & & 18.70 & 22.63 \\
& Rhodophyta & 6.59 & & & 1.74 & 15.57 \\
Autumn - Winter & Isopoda & & 19.93 & 4.64 & & 23.73 \\
& Rhodophyta & & 3.09 & 6.25 & & 10.62 \\
& Polychaeta & & 1.00 & 4.87 & & 7.87 \\
Autumn - Spring & Isopoda & & 19.93 & & 4.57 & 26.43 \\
& Rhodophyta & & 3.09 & & 1.74 & 7.79 \\
& Polychaeta & & 1.00 & & 2.09 & 6.04 \\
\cline { 3 - 5 } Winter - Spring & Rhodophyta & & & 6.25 & 1.74 & 12.73 \\
& Polychaeta & & & 4.87 & 2.09 & 12.51 \\
& Echinoidea & & & 5.76 & 0.58 & 8.60 \\
\hline & & & & & & \\
\hline
\end{tabular}

Table 4. SIMPER comparisons among size classes of juvenile Lithodes santolla in the San Jorge Gulf / Comparaciones SIMPER entre las distintas clases de talla de juveniles Lithodes santolla en el Golfo San Jorge

\begin{tabular}{|c|c|c|c|c|c|c|}
\hline \multirow{2}{*}{ Comparisons } & \multirow{2}{*}{ Prey } & \multicolumn{4}{|c|}{ Abundance in size class (CL mm) } & \multirow{2}{*}{$\begin{array}{l}\text { Dissimilarity } \\
\text { Contribution } \\
\quad(\%)\end{array}$} \\
\hline & & $<15$ & $15-25$ & $25-35$ & $>35$ & \\
\hline \multirow{3}{*}{$<15 ; 15-25$} & Bryozoa & 8.9 & 9.30 & & & 24.7 \\
\hline & Ophiuroidea & 3.47 & 9.40 & & & 16.92 \\
\hline & Isopoda & 1.71 & 5.82 & & & 10.53 \\
\hline \multirow[t]{3}{*}{$<15 ; 25-35$} & Ophiuroidea & 3.47 & & 20 & & 27.25 \\
\hline & Isopoda & 12.31 & & 5.82 & & 18.45 \\
\hline & Bryozoa & 8.92 & & 0.23 & & 10.50 \\
\hline \multirow[t]{3}{*}{$<15 ; 35$} & Ophiuroidea & 3.47 & & & 41.25 & 39.15 \\
\hline & Rhodophyta & 4.97 & & & 8.83 & 12.46 \\
\hline & Echinoidea & 0.53 & & & 7.25 & 8.04 \\
\hline \multirow[t]{3}{*}{$15-25 ; 25-35$} & Ophiuroidea & & 9.43 & 20 & & 28.01 \\
\hline & Isopoda & & 5.82 & 12.31 & & 18.45 \\
\hline & Bryozoa & & 9.23 & 0.23 & & 12.88 \\
\hline \multirow[t]{3}{*}{$15-25 ; 35$} & Ophiuroidea & & 9.43 & & 41.25 & 38.08 \\
\hline & Rhodophyta & & 4.64 & & 8.83 & 11.62 \\
\hline & Bryozoa & & 9.23 & & 0.00 & 9.73 \\
\hline \multirow[t]{3}{*}{$25-35 ; 35$} & Ophiuroidea & & & 20 & 41.25 & 39.90 \\
\hline & Isopoda & & & 12.31 & 7.5 & 14.56 \\
\hline & Rhodophyta & & & 4.19 & 8.83 & 11.96 \\
\hline
\end{tabular}


material (Feder et al. 1980). There is no data available on the natural food of SKC megalopa or if they feed. The small-sized juveniles (9-32 mm CL) of the golden king crab Lithodes aequispina predate on ophiuroids, sponges, algal debris, hydrozoans, bivalve molluscs and fishes, in a bathyal benthic habitat (Tarverdieva \& Zgurovsky 1985).

The main food items in juvenile SKC from the San Jorge Gulf were red algae, ophiuroids, isopods, polychaete worms, and bryozoans. Unidentified organic remains (UOR), which showed the highest frequency of occurrence, were remnants of soft tissues, chitinous parts of unidentified prey items and organic detrital material. Pirtle \& Stoner (2010) note that juvenile red king crabs removed the soft tissue of hydroids and bryozoans, without ingesting the capsule or theca. A similar process occurs with some mollusks. This may explain the high frequency of unidentifiable soft tissue in the stomach contents observed in this study.

The presence of sediment, cyanobacteria, foraminiferans, diatoms and ciliates, would be related to the capture, handling and processing of other prey prior to ingestion. It is possible that these items were ingested together with pieces of animals and algae that were scraped from the substrate by the chelipeds, as well as with particulate organic matter and associated bacteria. This feeding behaviour has been observed in laboratoryreared juvenile SKC (Vinuesa, unpublished data). The ingestion of sediment with organic detritus and bacteria has also been mentioned for postlarvae of the red king crab (Feder et al. 1980).

The presence of mollusks shell debris in many stomach content records does not ensure that the animal was preyed upon, and it is possible that many of these are incorporated during the intake of other animals or are with sediments or debris from intertidal levels. In fact, shell remains of Perumytilus purpuratus (Lamarck, 1819), an intertidal mussel, were found in some stomachs.

It is necessary to mention that the red alga Corallina sp., which has a high calcium carbonate content (Marsham et al. 2007), showed a high frequency of occurrence and was the most consumed algae. It is possible that its ingestion and assimilation would contribute to the increase of calcium storage needed after moult for hardening the new exoskeleton. The high requirement of calcium may also account for the high frequency of occurrence of the ophiuroid Ophiactis asperula (Philippi, 1858), with calcium-rich ossicles.
In this study, crabs in PMO, MOU and RPM have no content in their stomachs, and only LPM and INT crabs had food, to a greater or lesser amount. Similar findings were recorded in laboratory-reared juvenile females of the red king crab, where they stop feeding about 12 days before and 8 days after moult (Zhou et al. 1998). Juvenile crabs of both sexes moults during all seasons, and no relationship was observed with water temperature.

A high diversity of prey items suggests an opportunistic feeding behaviour, allowing them to make extensive use of environmental supply. The main prey species consumed by the southern king crab juveniles are abundant on the shallow rocky bottoms of the studied area: O. asperula, Pseudechinus magellanicus (Philippi, 1857) and Exosphaeroma lanceolatum (White, 1847). The former 2 are the most abundant ophiuroid and echinoid species, respectively, while the latter is the most abundant species of isopod in the area. Previous work on the settlement of algae and macrofauna in the same area, registered more than 120 species inhabiting subtidal rocky shores. Almost all prey items found here were mentioned in that report (Vinuesa $2008^{1}$ ), suggesting a close connection between the observed diet and prey availability. In addition, the impact of seasonal variation on the diet composition as found in this study might be related to the feeding strategy of juveniles. An opportunistic feeding behaviour may enhance seasonal variations in the diet composition due to changes in the abundance of the main prey items, and also minimize the foraging time by which the predator itself may be at risk.

The composition of prey species was similar in both sexes. This is expected because juvenile crabs use the same microhabitat regardless of sex, in contrast to what is sometimes observed for adult crabs. Differences in diet composition among size classes are related with a microhabitat shift in early life history stages.

Although all the crabs collected were of small sizes, they showed differences in CL of up to $40 \mathrm{~mm}$. Simulated growth process in immature SKC from the Beagle Channel indicates 6-7 moults per year, and sizes between 10 to 15 mm CL (Vinuesa et al. 1990, Vinuesa et al. 1991). Rearing of early juvenile stages in the laboratory for about 6 months indicates sizes of 5 to $6 \mathrm{~mm} \mathrm{CL}$, at temperatures of 9 and $15^{\circ} \mathrm{C}$, respectively (Calcagno et al. 2005), similar temperatures to those recorded in the San Jorge Gulf. In our study, results show higher individual growth variation during the first year, however never exceeding $20 \mathrm{~mm}$ CL. On this basis, the crabs analysed in this study would have had ages ranging between $0+$ and $2+$ years. 
Our results indicate that the diet is highly influenced by body size. Crabs less than $15 \mathrm{~mm}$ CL, were found to prey more often on bryozoans and isopods than larger crabs. A more pronounced change occurs after about 35$45 \mathrm{~mm}$ of CL, when juveniles migrate to deeper waters, on sandy and muddy bottoms. Here, juveniles over $70 \mathrm{~mm}$ CL and adults change diet and switch to a scavenging feeding behaviour (Balzi 1997).

Early juveniles of Paralithodes camtschaticus are most abundant in complex physical substrates, such as rock rubble, cobbles, pebbles and broken shells (Sundberg \& Clausen 1977, Loher \& Armstrong 2000). According to Pirtle \& Stoner (2010), food availability and biological qualities of substrate are more important than physical qualities for habitat selection of early juvenile red king crabs. Southern king crabs in early crab stages (between approximately 2-10 $\mathrm{mm} \mathrm{CL}$ ) were not commonly found by divers, but some unusual captures were made during the present study. Previously, these small crabs were only found stranded on rocky shores after severe storms along with seaweeds, shellfish and other invertebrates. These early stages probably remain in cryptic microhabitats, isolated from local predators, such as fishes (Sebastes oculatus Valenciennes, 1833 and Notothenia angustata Hutton, 1875), red octopus Enteroctopus megalocyathus (Gould, 1852), and older juveniles SKC, especially those of the previous year class. Cannibalism occurs widely in decapods, especially in experimental conditions. This phenomenon has been well documented in king crabs (Brodersen et al. 1990, Rounds et al. 1990, Stevens \& Swiney 2005), particularly among specimens of different sizes, and was a significant problem in the aquaculture of red king crabs (Stoner 2009). During our study we have not found evidence of cannibalism among juveniles of $L$. santolla.

In the coastal and central region of the San Jorge Gulf, juveniles $<40 \mathrm{~mm}$ CL are usually associated with small cracks and crevices in the rocks and biogenic complex habitats, with algal beds, mainly Macrocystis pyrifera, Corallina spp., and other filamentous and laminar red algae, sessile animals, e.g., sponges, hydrozoan and bryozoan colonies, anemones, and ribbed mussel Aulacomya atra (Molina, 1782) beds. The complex physical structure of kelp forests, algal mats, and other biogenic habitats, such as the ribbed mussel beds, provide important structural features, food and available spaces for settlement and recruitment of crabs and other invertebrates.

Habitat requirements for larval settlement and juvenile grow-out of commercially important crustacean species has been studied worldwide, including in estuaries and deep waters. Dungeness crab Cancer magister requires substrates containing shell hash during the first year of life (Armstrong \& Gunderson 1985). A similar association was reported for juveniles of the blue king crab Paralithodes platypus Brandt, 1850 from the Pribiloff Islands (Armstrong et al. 1985). A higher proportion of juveniles of the red king crab P. camtschaticus were found more often in coastal rocky areas than in less sheltered, open areas (Sundberg \& Clausen 1977). Moreover, the juveniles of this same species are known to use shallow sublittoral bottoms in the Barents Sea as habitat and feeding grounds (Pavlova 2008). The use of this type of habitat by L. santolla in San Jorge Gulf has been previously mentioned (Vinuesa 2001, Vinuesa \& Balzi 2002). It is believed that these coastal areas are nursery habitats of great importance for the sustainable exploitation of this fishery resource. Thus, it is important to consider the conservation of coastal rocky shores to ensure successful recruitment of SKC populations within the San Jorge Gulf.

\section{ACKNOWLeDgments}

We appreciate the assistance of Mr. Héctor Durbas in the capture of juveniles SKC. To Dra. A. Boraso, for algae determination, and Drs. Gloria Alonso and J.J. López Gappa, for their help in determination of amphipods and bryozoans, respectively. To Lic. Damián Gil, for his useful comments on the manuscript and Lic. H. Zaixso, for his help in statistical methodology. This work was supported with grants from the Consejo Nacional de Investigaciones Científicas y Técnicas de Argentina (CONICET), complemented by another grant from the 'Proyecto Marino Patagónico’, Project PNUD-ARG 02/018.

\section{LITERATURE CITED}

Anger K, GA Lovrich, S Thatje \& JA Calcagno. 2004. Larval and early juvenile development of Lithodes santolla (Molina, 1782) (Decapoda: Anomura: Lithodidae) reared at different temperatures in the laboratory. Journal of Experimental Marine Biology and Ecology 306: 217-230.

Armstrong DA \& D Gunderson. 1985. The role of estuaries in Dungeness crab early life history: A case study in Grays Harbor, Washington. Alaska Sea Grant Dungeness crab Symposium, October 1984, Anchorage 85: 145-170.

Armstrong DA, JL Armstrong, R Palacios, G Williams, JC Jensen \& W Pearson. 1985. Early life history of juvenile blue king crab, Paralithodes platypus, around the Pribiloff Islands. Proceedings of the International King Crab Symposium. Alaska Sea Grant Report, Anchorage 85: 211229. 
Balzi P. 1997. Los hábitos alimenticios de la centolla Lithodes santolla (Molina) del Golfo San Jorge. Naturalia Patagónica, Ciencias Biológicas, Argentina 5: 67-87.

Brodersen CC, PM Rounds \& MM Babcock. 1990. Diet influences cannibalism in laboratory-held juvenile red king crabs (Paralithodes camtschatica). Proceedings of the International Symposium on King and Tanner Crabs. Alaska Sea Grant College Program Report, Anchorage 90: 377382.

Calcagno JA, GA Lovrich, K Anger \& A Kaffenberger. 2004. Larval development in the Subantarctic king crabs Lithodes santolla (Molina) and Paralomis granulosa (Jacquinot) reared in the laboratory. Helgoland Marine Research 58: 11-14.

Calcagno JA, GA Lovrich, S Thatje, U Nettelman \& K Anger. 2005. First year growth in the lithodids Lithodes santolla and Paralomis granulosa reared at different temperatures. Journal of Sea Research 54: 221-230.

Campodónico I. 1971. Desarrollo larval de la centolla Lithodes antárctica Jacquinot en condiciones de laboratorio (Crustacea, Decapoda, Anomura: Lithodidae). Anales del Instituto de la Patagonia, Serie Ciencias Naturales 2: 181190.

Clarke KR \& RM Warwick. 2001. Change in marine communities: an approach to statistical analysis and interpretation, 172 pp. Primer-E Ltd, Plymouth Marine Laboratory, Plymouth.

Comoglio LI, GA Lovrich \& JH Vinuesa. 1990. Feeding habits of southern king crab, Lithodes santolla, and false king crab, Paralomis granulosa in the Beagle Channel. Proceedings of the International Symposium on King and Tanner Crabs. Alaska Sea Grant College Program Report, Anchorage 90: 315-325.

Feder HM \& SC Jewett. 1981. Feeding interactions in the Eastern Bering Sea with emphasize on the benthos. In: Hood DW \& JA Calder (eds). The Eastern Bering Sea Shelf: Oceanography and resources, pp. 1229-1261. Office of Marine Pollution Assessment, NOAA, Seattle.

Feder HM, K McCumby \& AJ Paul. 1980. The food of postlarval king crab, Paralithodes camtschatica, in Kachemak Bay, Alaska (Decapoda, Lithodidae). Crustaceana 39: 315318.

Feniuk VF. 1945. Analysis of stomach contents of king crab. Journal of the Pacific Science Research Institute, Marine Fisheries and Oceanography (TINRO), URSS 19: 71-78.

Guzmán LC \& C Ríos. 1985. Investigación, manejo y control de las pesquerías de centolla y centollón de la XII Región (1979-1983). Informe consolidado: Recurso centolla (Lithodes antarcticus Jacquinot). Informes, Instituto de la Patagonia, Chile 34: 1-259.

Herrnkind WF \& MJ Butler. 1986. Factors regulating postlarval settlement and juvenile microhabitat use by spiny lobsters Panulirus argus. Marine Ecology Progress Series 34: 23-30.
Jewett SC \& MH Feder. 1982. Food and feeding habits of the King Crab Paralithodes camtschatica near Kodiak Island, Alaska. Marine Biology 66: 243-250.

Jewett SC, LA Gardner \& PM Rusanowski. 1990. Food and feeding habits of red king crab from Northwestern Norton Sound, Alaska. Proceedings of the International Symposium on King and Tanner Crabs. Alaska Sea Grant College Program Report, Anchorage 90: 219-232.

Kattner G, M Graeve, JA Calcagno, GA Lovrich, S Thatje \& K Anger 2003. Lipid, fatty acid and protein utilization during lecithotrophic larval development of Lithodes santolla (Molina) and Paralomis granulosa (Jacquinot). Journal of Experimental Marine Biology and Ecology 292: 61-74.

Loher T \& DAArmstrong. 2000. Effects of habitat complexity and relative larval supply on the establishment of early benthic phase red king crab (Paralithodes camtschaticus Tilesius 1815) populations in Auke Bay, Alaska. Journal of Experimental Marine Biology and Ecology 245: 83-109.

Lovrich GA, S Thatje, JA Calcagno, K Anger \& A Kaffenberger. 2003. Changes in biomass and chemical composition during lecithotrophic larval development of the Southern king crab Lithodes santolla (Molina). Journal of Experimental Marine Biology and Ecology 288: 65-79.

Macpherson E. 1988. Revision of the family Lithodidae Samouelle, 1819 (Crustacea, Decapoda, Anomura) in the Atlantic Ocean. Monografias de Zoología Marina, Instituto de Ciencias del Mar, Barcelona 2: 9-153.

Marsham S, SW Scott \& ML Tobin. 2007. Comparison of nutritive chemistry of a range of temperate seaweeds. Food Chemistry 100: 1331-1336.

McLaughlin PA \& JF Hebard. 1961. Stomach contents of the Bering Sea king crabs. Bulletin International North Pacific Fisheries Commission 5: 5-8.

McLaughlin PA, KAnger, A Kaffenberger \& GALovrich. 2001. Megalopal and early juvenile development in Lithodes santolla (Molina, 1782) (Decapoda: Anomura: Paguroidea: Lithodidae), with notes on zoeal variations. Invertebrate Reproduction and Development 40: 53-67.

McLaughlin PA, KAnger, A Kaffenberger \& GALovrich. 2003. Larval and early juvenile development in Paralomis granulosa (Jacquinot) (Decapoda: Anomura: Paguroidea: Lithodidae), with emphasis on abdominal changes in megalopal and crab stages. Journal of Natural History 37: 1433-1452

Pavlova LV. 2008. Effect of juvenile red king crabs on zoobenthos in Kola Bay (Barents Sea). Doklady Biological Sciences, Vladivostok 422: 312-315.

Pirtle JL \& AW Stoner. 2010. Red king crab (Paralithodes camtschaticus) early post-settlement habitat choice: Structure, food, and ontogeny. Journal of Experimental Marine Biology and Ecology 393: 130-137.

Revuelta G \& G Andrade. 1978. Nueva localidad para Lithodes murrayi Henderson 1888 en el Pacífico Sur Oriental. Noticiario Mensual, Museo Nacional de Historia Natural, Chile 22: 3-4. 
Rounds PM, C Brodersen \& M Babcock. 1990. Effects of cohort density and habitat on survival and growth of juvenile red king crab, Paralithodes camtschatica. Proceedings of the International Symposium on King and Tanner Crabs. Alaska Sea Grant College Program Report, Anchorage 90: 209-217.

Sokal RR \& FJ Rohlf. 1995. Biometry. The principles and practice of statistics in biological research, 937 pp. WH Freeman and Co, New York.

Stevens BG \& KM Swiney. 2005. Post-settlement effects of habitat type and predator size on cannibalism of glaucothoe and juveniles of red king crab Paralithodes camtschaticus. Journal of Experimental Marine Biology and Ecology 321: $1-11$.

Stoner AW. 2009. Habitat-mediated survival of newly settled red king crab in the presence of a predatory fish: Role of habitat complexity and heterogeneity. Journal of Experimental Marine Biology and Ecology 382: 54-60.

Stuardo J \& I Solís. 1963. Biometría y observaciones generales sobre la biología de Lithodes antarcticus Jacquinot. Gayana, Zoología 11: 1-49.

Sundberg K \& J Clausen. 1977. Post-larval king crab (Paralithodes camtschatica) distribution and abundance in Kachemak Bay, lower Cook Inlet, Alaska, 1976. In: Trasky LL, LB Flagg \& DC Burbank (eds). Environmental Studies of Kachemak Bay and Lower Cook Inlet, Alaska Department Fish and Game 5: 1-36.

Takeuchi I. 1959. Food of king crab (Paralithodes camtschatica) off the west coast of Kamtchatka in 1958. Bulletin of Hokkaido Regional Fisheries Research Laboratory 20: 67-75.

Takeuchi I. 1967. Food of king crab, Paralithodes camtschatica, off the west coast of Kamtchatka Peninsula, 1958-64. Bulletin of the Japan Sea Regional Fisheries Research Laboratory 33: 32-44.

Tarverdieva MI. 1976. Feeding of the Kamtchatka king crab Paralithodes camtschatica and Tanner crabs Chionoecetes bairdi and Chionoecetes opilio in the southeastern part of the Behring Sea. Biologiya Morya 2: 34-39.

Tarverdieva MI \& KA Zgurovski. 1985. On food composition of the deep-water crab species Lithodes aequispina Benedict and Chionoecetes tanneri Rathbun in the Behring and Okhotsk seas. Proceedings of the International King Crab Symposium. Alaska Sea Grant Report, Anchorage 85: 319329.
Vinuesa JH. 2001. Algunos aspectos biológicos de la centolla Lithodes santolla y su captura en el Golfo San Jorge, en 2000. Contribuciones Científicas del Centro Austral de Investigaciones Científicas, Argentina 36: 1-14.

Vinuesa JH. 2005. La distribución de los Crustáceos Decápodos y Estomatópodos en el Golfo San Jorge. Revista de Biología Marina y Oceanografía 40: 7-21.

Vinuesa JH \& P Balzi. 2002. Reproductive biology of Lithodes santolla in the San Jorge Gulf, Argentina. In: Paul AA, EG Dawe, R Elner, GS Jamieson, GH Kruse, R Otto, B SainteMarie, TC Shirley \& D Woodby (eds). High latitude crabs: Biology, management, and economics, pp. 283-304. University of Alaska Sea Grant College Program, Fairbanks.

Vinuesa JH, L Ferrari \& RJ Lombardo. 1985. Effect of temperature and salinity on larval development of southern King crab (Lithodes antarcticus). Marine Biology 85: 8387.

Vinuesa JH, LI Comoglio \& GA Lovrich. 1990. Growth of immature Southern King Crab, Lithodes santolla, in the Beagle Channel. Proceedings of the International Symposium on King \& Tanner Crabs, Nov. 1989, Anchorage, pp. 259269.

Vinuesa JH, GA Lovrich \& LI Comoglio. 1991. Maduración sexual y crecimiento de las hembras de centolla Lithodes santolla (Molina, 1782) en el Canal Beagle. Biota, Chile 7: 7-13.

Vinuesa JH, GA Lovrich \& F Tapella. 1999. New localities for Crustacea Decapoda in the Magellan Region, Southern South America. Scientia Marina 63: 321-323.

Vinuesa JH, M Varisco \& F Escriche. 2011. Settlement and recruitment of the crab Halicarcinus planatus (Crustacea: Decapoda: Hymenosomatidae) in Golfo San Jorge. Journal of the Marine Biological Association of the United Kingdom 91: 685-690.

Zhou S, TC Shirley \& GH Kruse. 1998. Feeding and growth of the red king crab Paralithodes camtschaticus under laboratory conditions. Journal of Crustacean Biology 18: 337-345. 